\title{
HUBUNGAN ANTARA DUKUNGAN SOSIAL DENGAN PENERIMAAN DIRI PADA PASIEN WANITA PENDERITA KANKER PAYUDARA PASCA MASTEKTOMI DI RUMAH SAKIT ISLAM SULTAN AGUNG SEMARANG
}

\author{
Alfira Sukmawati dan Ratna Supradewi \\ Fakultas Psikologi Universitas Islam Sultan Agung, Jl Kaligawe Raya km 4, Semarang \\ E-mail: ratnavina4@gmail.com
}

\begin{abstract}
Abstrak
Penelitian ini bertujuan untuk mengetahui hubungan antara dukungan sosial dengan penerimaan diri wanita pasien kanker payudara.Penelitian ini menggunakan metode kuantitatif korelasional dengan subjek berjumlah 80 pasien kanker payudara. Teknik dalam pengambilan sampel menggunakan teknik purposive sampling. Metode pengumpulan data menggunakan skala penerimaan diri dan dukungan sosial. Skala penerimaan diri berjumlah 25aitem berdaya beda tinggi dengan koefisien korelasi skor aitem total bergerak antara 0,364 - 0,739 dengan reliabilitas 0,928. Sedangkan skala dukungan sosial berjumlah 29 aitem berdaya beda tinggi dengan koefisien korelasi skor aitem total bergerak antara 0,341-0,693 dengan skor reliabilitas sebesar 0,914. Hasil analisis uji normalitas dari data penerimaan diri menunjukkan nilai KS-Z sebesar 1,176 dengan taraf signifikansi sebesar $0,126(p>0,05)$ dan hasil analisis data dukungan sosial menunjukkan nilai KS-Z sebesar 0,998 dengan $P=0,273$ $(p>0,05)$. Hasil uji linieritas antara variabel penerimaan diri dengan variabel dukungan sosial diperoleh skor $F_{\text {linier }}$ sebesar 137,788 dengan taraf signifikasi $p=0.000(p<0.05)$. Uji hipotesis menggunakan teknik analisis Product Moment dengan $r_{x y}=0,799$ dengan taraf signifikansi $p=0.000(p<0,01)$ yang menunjukkan ada hubungan positif yang signifikan antara dukungan sosial dengan penerimaan diri wanita pasien kanker payudara di rumah sakit Islam Sultan Agung Semarang. Variable dukungan sosial memberikan sumbangan efektif sebesar $63,9 \%$ terhadap penerimaan diri, sisanya $36,1 \%$ dipengaruhi oleh faktor yang lain.
\end{abstract}

Kata kunci : Penerimaan Diri, Dukungan Sosial

\section{THE RELATIONSHIP BETWEEN SOCIAL SUPPORT WITH SELF-ACCEPTANCE ON WOMEN PATIENTS WITH POST-MASTECTOMY BREAST CANCER IN ISLAMIC HOSPITAL OF SULTAN AGUNG SEMARANG}

\begin{abstract}
The self-acceptance of breast cancer patients is an attitude of fully accepting oneself, not feeling shy of their circumstances and trying to think positively with the condition that they experience. Self-acceptance can be influenced by several factors one of which is social support. This research aims to identify the relationship between the social support with self-acceptance of breast cancer patients. This research uses the quantitative correlational method. The subjects in this research amounted to 80 breast cancer patients. The sampling technique used in this research uses the purposive sampling technique. Methods of data collection using an self acceptance scale and scale of social support. Self acceptance scale obtained 25 high-powered aitem with correlation coefficient of moving aitem score total between 0,364-0,739 with reliability 0,928. While the scale of social support obtained 29 high-powered aitem with the correlation coefficient of moving aitem score total between 0,341-0,693 with reliability sebasar 0,914. The Result of normality test analysis of the self acceptance showed a KS-Z value of 1,176 with a significance level of 0,126 ( $p>0.05)$ and social support showed a KS-Z value of 0,998 with $P=0.273$ ( $p>0.05$ ). Result of linearity test between self acceptance variable with social support variablse obtained by $F_{\text {linier }}$ score 137,788 with signification level $p=0.000$ ( $\left.p<0.05\right)$. Hypothesis test using Product Moment analysis technique with $r_{x y}=0,799$ with significance level $p=0.000(p<0,01)$ indicating there is significant positive correlation between social support with self-acceptance of

32 E-ISSN 2656-4173
\end{abstract}


patients with post-mastectomy breast cancer in islamic hospital of sultan agung semarang. Social support variables contributed $63,9 \%$ to the self acceptance, the remaining $36,1 \%$ influenced through other factors.

Keywords : Self-Acceptance, Social Support

\section{Pendahuluan}

Kanker payudara adalah sebuah penyeberan sel kanker abnormal yang menyerang anggota tubuh dibagian payudara. Kanker payudara berawal pada sel-sel yang telah melapisi duktus (kanker duktal), dan beberapa berawal di lobulus (kanker lobular), serta sebagian kecil berasal pada jaringan dibagian lain (Novianti \& Purnami, 2012). Berdasarkan data dari (Kementerian Kesehatan, 2015) menyatakan bahwa penyakit kanker payudara adalah penyakit kanker dengan perkembangan penyakit yang tertinggi di Indonesia pada tahun 2013, yaitu sebesar 0,5\% yang terbagi kedalam Provinsi D.I. Yogyakarta, provinsi Kepulauan Riau, Provinsi Maluku Utara, Provinsi Jawa Tengah dan Provinsi Jawa Timur. Menurut Purwoastuti (Sumiatin, 2013) mengatakan bahwa prevalensi (populasi yang mengalami penyakit) kanker payudara di negara Indonesia adalah 10-20 dari 100.000 penduduk terkena penyakit tersebut.

Berdasarkan informasi dari Kementerian Kesehatan (2015) faktor risiko terkena kanker diantaranya yaitu faktor genetik, faktor karsinogen (virus, hormon, zat kimia, iritasi kronis, dan radiasi), serta faktor gaya hidup (kurang berolahraga, mengkonsumsi alkohol, pola makan yang tidak baik dan merokok). Menurut Rasjidi (2010) bahwa risiko kanker payudara pada wanita meliputi faktor diet (seperti obesitas dan konsumsi alkohol), kemudian faktor genetik (dari anggota keluarga dengan riwayat kanker payudara atau juga dengan riwayat kanker ovarium) dan faktor reproduksi (kehamilan pertama pada usia lanjut, usia menache dini, masa laktasi, paritas yang rendah).

Ada berbagai macam cara dalam pengobatan kanker payudara, salah satunya dengan cara mastektomi,yaitu pengobatan penyakit kanker payudara dengan cara melakukan pengangkatan seluruh jaringan payudara (Mahleda \& Hartini, 2012). Mastektomi bisa dilakukan pada pasien kanker payudara stadium II dan III yang berguna untuk mencegah proses berkembangnya sel kanker dan memiliki taraf kesembuhan 85\% hingga 87\% (Dewi dkk, 2004).

Cara pengobatan penyakit kanker payudara semakin canggih sekalipun penyakit yang ganas yang banyak diderita oleh kaum wanita dengan cara tindakan operasi dimana bagian dari payudara harus diangkat atau disisihkan (mastektomi) akan tetap berdampak pada masalah fisiologis, psikologis dan sosial bagi pasien (Mahleda \& Hartini, 2012). Masalah fisiologis yang dialami seperti merasakan sakit yang merupakan efek jangka panjang dari mastektomi. Gejala psikologis yang muncul pada pasien kanker payudara diantaranya kecemasan, kemarahan dan depresi (Mahleda \& Hartini, 2012). Kemarahan yang terjadi pada pasien terkait dengan adaya tahapan-tahapan dalam penerimaan diri.

Feist \& Feist (2006) menjelaskan kekurangan yang ada pada salah satu bagian pada tubuh individu akan berpengaruh pada individu tersebut secara keseluruhan. Penerimaan diri merupakan suatu sikap seseorang mampu menerima dengan lapang dada apa yang terjadi pada dirinya, namun masih memiliki kemauan untuk mengubahnya, dalam kasus ini pasien yang memiliki penerimaan diri yang baik pasti memiliki kemauan untuk sembuh dan mengobatinya, sedangkan seseorang yang memiliki penerimaan diri buruk akibat dari penyakit kanker payudara memunculkan sikap khawatir, tertekan, dan harga diri rendah. Faktor-faktor yang mampu mempengaruhi besarnya penerimaan diri seseorang salah satunya yaitu dukungan sosial. 
Individu yang sedang dalam menghadapi masalah membutuhkan orang lain untuk memberikan dukungan. Berdasarkan penjelasan diatas pada kasus orang-orang yang terkena suatu penyakit seperti kanker payudara, pasti sangat membutuhkan dukungan sosial dari orang-orang terdekatnya baik suami, anak, keluarga, maupun tim medis, atau kaum agamawan untuk memberikan dukungan kepada pasien agar memiliki kemauan yang tinggi untuk bertahan hidup. Seperti yang dijelaskan oleh Johnson dan Jhonson (Saputri \& Indrawati, 2011) bahwa dukungan sosial adalah pentingnya kehadiran individu lain yang mampu memberikan semangat, rasa menerima, perhatian dan bantuan hingga mampu meningkatkan kesejahteraan hidup bagi individu yang bersangkutan. Pada penelitian sebelumnya yang dilakukan oleh Utami (2013) dengan judul hubungan antara dukungan sosial keluarga dengan penerimaan diri individu yang mengalami asma dengan sampel dalam penelitian ini adalah individu yang mengalami asma di Rumah Sakit Umum Daerah Sanjiwani Gianyar yang berjumlah 105 individu yang mengalami asma diperoleh hasil analisis korelasi pearson dengan $r$ sebesar 0,687 dengan interpretasi antara dukungan sosial keluarga dengan penerimaan diri individu yang mengalami asma memiliki hubungan yang positif. Penelitian sebelumnya juga dilakukan oleh Ratnasari (2012) dengan judul hubungan dukungan sosial dengan kualitas hidup pada penderita tuberkulosis paru (TB Paru) di balai pengobatan penyakit paru (BP4) Yogyakarta unit minggiran dengan menggunakan metode penelitian non eksperimental yang bersifat kuantitatif. $s$ Berdasarkan hasil perhitungan analasis korelasi product moment pearson didapatkan hasil dari hubungan antara dukungan sosial dengan kualitas hidup pada pasien TB paru dengan $r=0,675(p<0,01)$, yang berarti bahwa terdapat hubungan yang signifikan antara dukungan sosial dengan kualitas hidup.

\section{Penerimaan Diri}

Johada (Rizkiana \& Retnaningsih, 2009) mengatakan bahwa penerimaan diri artinya sudah belajar untuk hidup dengan dirinya sendiri, maksudnya individu sudah menerima kekurangan dan juga kelebihan yang telah ditemukan pada dirinya. Gea dkk., (2002) menyatakan bahwa penerimaan diri merupakan suatu sikap kepada diri serta bagaimana memperlakukan diri sendiri secara baik dan diiringgi rasa senang dan bangga. Pada sikap menerima diri dibutuhkan kesadaran akan keinginan dalam melihat realita yang ada, baik secara fisik maupun secara psikis menyangkut berbagai ketidaksempurnaan dan kekurangan yang ada pada diri individu. Sari \& Nuryoto (2002) menyatakan bahwa ada dua faktor yang berpengaruh pada penerimaan diri individu antara lain

a. Pendidikan.

Individu yang memiliki tingkat pendidikan yang lebih tinggi cenderung mempunyai kesadaran yang akan lebih baik dalam memahami serta memandang diri.

b. Dukungan sosial.

Individu yang memiliki dukungan sosial yang baik akan cenderung mendapatkan perlakuan yang lebih baik serta menyenangkan, sehingga dapat memunculkan perasaan akan rasa aman dan kepercayaan di dalam diri. Sobur (2009) menyatakan bahwa faktor - faktor yang menghambat penerimaan diri individu antara lain individu selalu berfikiran negatif mengenai masa depan, adanya perilaku para anggota masyarakat yang tidak menyenangkan atau kurang terbuka, adanya hambatan emosional yang berat, terdapat hambatan dalam lingkungan.

34 
Aspek - aspek dari penerimaan diri menurut Sheerer (Ulina dkk., 2013) dapat dibedakan menjadi 9 aspek yaitu

a. Percaya pada kemampuan diri

Individu yang telah memiliki potensi dalam menjalani kehidupan, dapat dilihat dari cara individu bersikap yang memiliki kepercayaan diri, dimana individu tersebut lebih menyukai pengembangan sikap yang baik serta membuang sikap buruknya dan tetap menjadi diri sendiri dengan perubahan yang positif. Hal ini dapat membuat individu merasa puas terhadap perilaku dan keputusan sendiri.

b. Perasaan sederajat

Individu merasa dirinya sebagai manusia yang berharga dan juga sederajat atau setara dengan orang lain pada umumnya. Hal ini menjadikan individu tersebut merasa sebagai seseorang yang memang memiliki kelebihan dan kelemahan seperti halnya orang lain.

c. Menyadari keterbatasannya

Individu tidak menyangkali adanya keterbatasan yang ada pada dirinya serta tidak mengingkari kelebihan, dan mempunyai penilaian yang realistik terhadap sumber daya yang dimiliki.

d. Orientasi keluar diri

Individu yang lebih memiliki orientasi keluar dirinya daripada ke dalam diri. Individu yang seperti ini cenderung memiliki kepedulian dan toleran terhadap orang lain, sehingga membuatnya dapat diterima oleh lingkungannya.

e. Berani memikul tanggung jawab

Individu yang berani bertanggung jawab terhadap perilakunya terlihat pada sifat individu yang mampu menerima kritikan dan menjadikan kritikan tersebut sebagai suatu masukan yang baik dan penting untuk mengembangkan dirinya.

f. Berpendirian

Individu yang memiliki pendirian adalah individu yang dapat mengikuti keputusan diri sendiri daripada bersikap konformitas terhadap tekanan sosial. Individu seperti ini biasanya memiliki ide aspirasi untuk kehidupan dan pengharapan diri yang lebih baik.

g. Menerima pujiaan dan celaan secara objektif

Individu mampu menerima pujian atas perilakunya yang baik serta dapat menerima kritikan sebagai bahan untuk mengevaluasi kesalahan diri.

h. Menerima sifat kemanusiaan

Individu mampu mengeluarkan dan mengenali segala bentuk emosinya seperti perasaan marah, seih, takut, senang tanpa menganggap emosi tersebut sebagai sesuatu yang harus di tutupi karena itu merupakan sifat kemanusiaan yang dimiliki oleh setiap orang.

i. Tidak menganiaya dirinya sendiri

Individu mampu menyesuaikan diri dengan baik terhadap lingkungan tanpa merasa dirinya tidak berharga, merasa diri sebagai individu yang menyimpang dan ditolak oleh orang lainAspek-aspek tersebut digunakan dalam penelitian ini, karena sesuai dengan kondisi psikologis pasien yang menderita suatu penyakit. Tomb (2003) menjelaskan tentang tahapan - tahapan penerimaan diri sebagai berikut:

a. Tahap Denial 
Pada tahap ini berupa penyangkalan atau pengelakkan atas kejadian yang tidak menyenangkan ataupun pada kekurangan yang dimiliki individu.

b. Tahap Anger

Pada tahap ini berupa reaksi emosi seperti marah atas kejadian dan kenyataan yang dialami individu tersebut.

c. Tahap Bergaining

Pada tahap ini individu mengalihkan reaksi emosinya atau kemarahan dengan lebih baik yaitu dapat dengan cara yang biasanya berhubungan dengan penawar untuk mendapatkan sesuatu yang lebih sering kali berbentuk kesepakatan dengan Tuhan.

d. Tahap Depression

Pada tahap ini individu memunculkan reaksi dalam bentuk kehilangan harapan dan putus asa.

e. Tahap Acceptance

Pada tahap ini di mana individu telah mencapai pada titik kepasrahan diri dan perasaan untuk berusaha menerima kenyataan buruk yang dialami atau yang sedang terjadi.

Germer (Ardani \& Nasution, 2015) juga memiliki penjelasam bahwa penerimaan diri dilalui dalam beberapa tahap yaitu:

a. Tahap Aversion

Pada tahap ini ditandai dengan munculnya perasaan benci/ketidakinginan serta berusaha menghindari rasa benci tersebut dengan cara merenung untuk mencari cara bagaimana menghilangkan perasaan tersebut.

b. Tahap Curiosity

Pada tahap ini individu melawan rasa benci atau ketidaknyamanannya dengan perhatian. individu mulai memiliki pemikiran akan pertanyaan-pertanyaan pada hal-hal yang dirasa perlu untuk diperhatikan.

c. Tahap Tolerance

Pada tahap ini individu mulai mampu menerima kejadian yang menimpanya dengan baik. Dalam hal ini toleransi berarti mampu menanggung rasa sakit karena berbagai emosi negatif muncul sebelumnya dan individu berusaha terus melawan dan mengharapkan perasaan tersebut dapat cepat hilang.

d. Tahap Allowing

Pada tahap ini individu telah berusaha membiarkan emosinya datang dan pergi, dimana emosi tersebut merupakan perasaan tidak nyamannya yang akan dibiarkan datang dan pergi dengan sendirinya.

e. Tahap Friendship

Pada tahap ini individu sudah mampu memegang erat dan memandang nilai-nilai yang telah tersembunyi. Individu memandang nilai-nilai pada dirinya pada saat berada dalam keadaan yang sulit yang sedang menimpanya.

\section{Dukungan Sosial}

Sarafino (2011) menjelaskan bahwa dukungan sosial merupakan suatu bentuk bantuan berupa emosi, informasi dan materi yang diberikan oleh individu lain yang paling dekat seperti sahabat, 
saudara, keluarga atau kerabat dekat lainnya yang akrab pada individu yang bersangkutan. Rensi dan Sugarti (Waqiati dkk, 2013) juga memiliki penjelasan bahwa dukungan sosial adalah suatu bentuk proses evaluasi individu kepada bantuan yang diberikan kepadanya dari orang-orang disekitarnya yang mencakup pemberian perhatian secara emosi, pemberian nasehat atau informasi, baik bersifat verbal atau non verbal, bantuan instrumental, yang membuat individu merasa dipedulikan. Faktor - faktor yang mempengaruhi dukungan sosial menurut Stanley (Azis \& Fatma, 2013) anatara lain :

a. Kebutuhan fisik

Kebutuhan fisik menjadi pengaruh dukungan sosial yaitu berupa sandang, papan, dan pangan. Jika individu merasa kebutuhan fisiknya tidak tercukupi, maka individu tersebut akan kurang mendapatkan dukungan sosial.

b. Kebutuhan sosial

Individu yang menempatkan dirinya secara baik, maka individu akan lebih dapat dikenal oleh masyarakat sekitar daripada individu yang tidak melakukan sikap sosial di masyarakat. Individu yang memiliki cara penempatan diri dengan baik cenderung menginginkan pengakuan dari masyarakat disekitarnya. Maka dari itu pengakuan sangat dibutuhkan dalam memberikan penghargaan.

c. Kebutuhan psikis

Pada kebutuhan psikis seperti halnya perasaan religius, rasa keingin tahuan, dan rasa aman tidak akan terpenuhi tanpa adanya pertolongan dari individu lain. Individu yang lagi mendapatkan masalah baik masalah tersebut ringan maupun yang berat, maka individu tersebut cenderung akan mencari dukungan sosial dari individu lain disekitar.

Aspek-aspek dari dukungan sosial menurut Sarafino (2011) anatara lain

a. Emotional support, mengacu kepada pemberian rasa hangat, memberikan perhatian, memberikan semangat, rasa percaya, empati, emosi dan cinta kasih, sehingga memunculkan kenyamanan pada individu dan membuatnya percaya bahwa ia telah dicintai, dihargai, dikagumi dan bahwa individu lain akan memberikan rasa aman dan perhatian pada individu tersebut.

b. Instrumental Support, tertuju pada menyediakan benda - benda dan layanan untuk menyelesaikan permasalahan seperti memberikan pinjaman uang dan membantu menyelesaikan permasalahan-permasalahan yang dialami individu.

c. Informational support, terbagi kedalam dua bentuk, yaitu bentuk pemberian informasi yang dapat membantu individu dalam menilai performance diri serta bentuk pemberian informasi atau pengajaran suatu keahlian yang bisa memberikan pemecahan pada suatu masalah.

d. Companionship Support, berupa menghabiskan waktu bersama dalam aktivitas-aktivitas yang santai seperti berlibur atau rekreasi diwaktu senggang, juga bisa berbentuk lelucon untuk menghibur, dapat pula melakukan kegiatan yang dapat memberikan perasaan senang atau membicarakan minat.

Sumber-sumber pada dukungan sosial umumnya didapatkan dari orang-orang yang dikasihi dan yang terdekat. (Sarafino, 2011) menyebutkan bahwa dukungan sosial bisa berasal dari berbagai macam sumber, seperti keluarga, dokter, teman, pasangan, rekan kerja, atau komunitas. Selanjutnya Goetlieb (Maslihah, 2011) mengatakan bahwa terdapat dua bentuk 
dukungan sosial, yaitu pertama dalam bentuk hubungan yang profesional yaitu berasal dari orangorang yang ahli pada bidangnya seperti dokter, psikiater, psikolog, konselor, maupun pengacara. Kemudian yang kedua dalam bentuk hubungan yang non profesional, yaitu yang berasal dari kerabat terdekat seperti dari keluarga dan teman.

\section{Kanker Payudara}

\section{Pengertian Kanker Payudara}

Kanker payudara adalah suatu penyakit yang mampu menyebabkan kematian terhadap perempuan, dimana terjadinya dikarenakan timbulnya kerusakan pada gen yang berfungsi dalam mengatur diferensiasi dan pertuumbuhan sehingga sel tersebut tumbuh dan berkembang tanpa bisa terkendalikan sehingga bisa menyebar melewati aliran darah keseluruh tubuh (Subagja, 2014). World Health Organization (WHO) menyebutkan kanker payudara kedalam urutan dengan nomer kode 17 pada International Classification of Diseases (ICD) (Subagja, 2014).

\section{Faktor risiko kanker payudara}

(Sjamjuhidajat, 2010) menjelaskan bahwa faktor-faktor lain yang memiliki risiko terjadinya kanker payudara adalah:

a. Faktor hereditas

Pada penelitian Sjamjuhidajat (2010), didapatkan berdasarkan 465 orang pasien yang terkena kanker pada payudara bahwa dari $25,8 \%$ banyaknya kasus memiliki saudara yang berjenis kelamin perempuan telah sama mengalami kanker payudara.

b. Faktor Paritas

Suatu penelitian menunjukkan bahwa pada kasus perempuan yang belum menikah, risiko terkena kanker pada bagian payudara 3,5 kali lebih besar dibanding pada perempuan yang sudah menikah. Individu yang sudah melahirkan banyak anak mampu menjadi salah satu faktor pencegah agar terhindar dari kanker payudara. Hal tersebut dikarenakan setelah persalinan terdapat proses laktasi (menyusui) yang dapat mengecilkan risiko terkena kanker payudara.

c. Faktor menyusui

Berdasarkan beberapa dari penelitian telah menunjukkan bahwa adanya korelasi dalam memberikan ASI dengan penurunan risiko perkembangan kanker pada payudara. Beberapa peneliti menjelaskan bahwa pada seorang ibu yang lebih lama dalam memberi ASI kepada bayinya maka akan semakin lebih baik. Hal ini berdasarkan pada teori yang menyebutkan bahwa kanker payudara berhubungan dengan salah satu hormon yaitu estrogen, dengan memberikan ASI secara berulang dapat meminimalkan risiko individu dalam terserang penyakit kanker payudara.

d. Faktor Usia

Perempuan yang telah melakukan proses melahirkan dalam pertama kalinya pada usianya yang < 20 tahun, memiliki risiko terserang kanker payudara sebesar 1\%, dibandingkan perempuan yang telah melahirkan pertama kalinya pada usia $>35$ tahun atau bahkan lebih akan memiliki risiko terkena sebesar 1,5\% hingga 5,3\%. 
e. Faktor menstruasi (menarche) dan menopause

Perempuan yang mengalami menstruasi diusia yang lebih muda memiliki risiko terserang kanker payudara lebih besar. Pada dasarnya risiko terkena kanker payudara akan turun sebesar $20 \%$ ketika menstruasi tertunda. Perempuan yang mengalami menstruasi lebih cepat (usia $<12$ tahun) dan terjadi siklus (perputaran waktu) menstruasi yang datang terasa lebih awal dapat meningkatkan risiko terkenanya sebesar empat kali dibanding pada perempuan yang menstruasi dalam usia $>13$. Menopause (perhentian masa haid) pada usia yang terlampau tua dapat meningkatkan risiko terkena kanker di bagian payudara. Pada perempuan yang mengalami menopause (perhentian masa haid) pada usia $>55$ tahun akan dua kali lebih besar risiko terserangnya dibanding pada perempuan yang menopause sebelum usia 45 tahun.

f. Faktor Obesitas

Perempuan yang mengalami obesitas atau berat badan yang berlebih mempunyai risiko $20 \%$ lebih banyak terkena kanker payudara. Karena obesitas mampu meningkatkan hormon estrogen dalam tubuh.

\section{Metode Penelitian}

Variabel yang digunakan dalam penelitian ini adalah sebagai berikut:

1. Variabel Bebas : Dukungan Sosial

2. Variabel Tergantung : Penerimaan Diri

Subjek dari penelitian ini adalah 80 pasien kanker payudara berjenis kelamin perempuan yang mastektomi. Populasi dalam penelitian ini adalah seluruh pasien wanita kanker payudara di Rumah Sakit Islam Sultan Agung, Semarang dengan kriteria berusia 20-60 tahun dan masih menjalani rawat jalan serta kemoterapi (rawat inap). Teknik dalam mengambil sampel pada penelitian ini adalah menggunakan purposive sampling. Sampel dari penelitian ini adalah menggunakan uji coba terpakai. Sebagai alasan peneliti dalam menggunakan uji coba terpakai dalam melakukan penelitian adalah dikarenakan karakteristik subjek yang spesifik serta ketersediaan subjek dirumah sakit yang tidak setiap waktu ada.

Alat ukur yang digunakan dalam penelitian ini adalah skala penerimaan diri dan skala dukungan sosial. Skala penerimaan diri berisi 36 aitem dengan 18 pernyataan favorable dan 18 pernyataan unfavorable, diperoleh 25 aitem yang berdaya beda tinggi dan memiliki koefisien korelasi skor aitem total bergerak dari 0,364-0,739 dengan reliabilitas 0,928. Skala dukungan sosial berisi 32 aitem dengan 16 pernyataan favorable dan 16 pernyataan unfavorable, terdapat 29 aitem yang berdaya beda tinggi dan memiliki koefisien korelasi skor aitem total bergerak dari 0,341-0,693 dengan reliabilitas 0,914. Uji hipotesis menggunakan teknik analisis Product Moment untuk menguji hipotesis dengan bantuan program SPSS versi 20.0 .

\section{Hasil}

Berdasarkan hasil analisis yang dilakukan oleh peneliti diperoleh skor korelasi $r_{x y}$ sebesar 0,799 dengan taraf signifikansi $p=0,000(p<0,01)$. Hal ini menunjukkan bahwa ada hubungan positif yang signifikan antara dukungan sosial dengan penerimaan diri pada wanita pasien kanker payudara pasca 
mastektomi di Rumah Sakit Islam Sultan Agung Semarang. Artinya, berarti semakin tinggi dukungan sosial yang didapat oleh individu, maka semakin tinggi pula penerimaan diri yang dimiliki, dan sebaliknya semakin rendah dukungan sosial yang didapatkan maka semakin rendah pula penerimaan diri yang dimiliki oleh individu tersebut.

\section{Pembahasan}

Pada hasil penelitian ini telah membuktikan bahwa ada hubungan positif yang signifikan antara dukungan sosial dengan penerimaan diri pada wanita pasien kanker payudara pasca mastektomi. Hasil uji korelasi yang membuktikan hal tersebut adalah pada skor sebesar 0,799 dengan taraf signifikansinya $p=0,000(p<0,01)$. Berdasarkan hal tersebut berarti semakin tinggi dukungan sosial yang didapat oleh individu, maka semakin tinggi pula penerimaan diri yang dimiliki, dan sebaliknya semakin rendah dukungan sosial yang didapatkan maka semakin rendah pula penerimaan diri yang dimiliki oleh individu tersebut.

Hasil penelitian tersebut senada dan menjadi penguat mengenai pendapat dari Rogers (Sari \& Reza, 2013) mengemukakan apabila individu mendapat penerimaan yang positif dari individu lainnya, maka individu tersebut cenderung akan mengembangkan sikap yang lebih positif kepada diri sendiri dan lebih mampu menerima dirinya. Penerimaan diri merupakan suatu tingkat kesadaran yang ada pada diri individu mengenai karakteristik kepribadiannya dan memiliki keinginan untuk dapat hidup dengan kondisi tersebut, hal ini berarti individu tersebut mempunyai pengetahuan mengenai dirinya sehingga dapat menerima kelemahan dan kelebihannya (Cooper, 2003). Artinya dengan adanya orang lain sebagai pendukung secara psikologis, maka dapat membantu individu mampu menerima keadaan diri nya secara realistik.

Dukungan sosial dalam penelitian ini berkontribusi cukup besar yaitu sebesar $61,25 \%$ yang berarti berperan penting dalam memuculkan adanya penerimaan diri pada wanita pasien kanker payudara pasca mastektomi. Setelah wanita pasien kanker payudara melakukan mastektomi (pengangkatan payudara) dapat membuat pasien merasa rendah dan mencela dirinya sendiri karena merasa adanya keterbatasan fisik pasca mastectomi tersebut, tetapi hal ini dapat membuat pasien mampu menerima dirinya dengan baik, yaitu dengan adanya dukungan sosial dari kerabat dekat pasien seperti keluarga, teman-teman dan orang lain disekitarnya dengan cara memberi dukungan dan arahan yang positif seperti membiarkan pasien bercerita segala hal yang diinginkan, memberikan perhatian, menghargainya, serta dapat pulamemberikan bantuan secara materil. Hal ini sesuai dengan pendapat (Baron \& Byrne, 2000) yang mengatakan bahwa pasien yang lagi dalam masa pengobatan akan dapat lebih cepat mendapat kesembuhan jika memiliki keluarga atau kerabat dekat yang mampu memberikan bantuan atau memberi dukungan baik secara materi maupun psikologis.

\section{Kesimpulan}

Berdasarkan hasil penelitian serta pembahasan yang telah dijelaskan dan dipaparkan sebelumnya, maka dapat disimpulkan bahwa ada hubungan positif yang signifikan antara dukungan sosial dengan penerimaan diri pada wanita pasien kanker payudara pasca mastektomi, dengan skor korelasi $r_{x y}$ sebesar 0,799 dengan taraf signifikansi $p=0,000(p<0,01)$. Sumbangan efektif yang diberikan variabel dukungan sosial terhadap penerimaan diri adalah $\mathrm{R}^{2}$ sebesar 0,639 atau $63,9 \%$ sedangkan sisanya $36,1 \%$ dipengaruhi variabel lain diluar penelitian ini seperti stress, emosional, harga diri, optimisme, dan kecemasan. Hal ini berarti hipotesis diterima.

40 \begin{tabular}{l|ll}
\hline & E-ISSN $2656-4173$ \\
P-ISSN $1907-8455$
\end{tabular} 


\section{Saran}

1. Bagi Penderita kanker payudara

Penderita kanker payudara diharapkan selalu dapat berpikir positif, berprasangka baik, dan mengikuti saran-saran yang diberikan oleh orang - orang disekitarnya.

2. Bagi orang-orang terdekat penderita kanker payudara

Bagi orang-orang terdekat penderita diharapkan mampu mempertahankan atau lebih meningkatkan pemberian dukungan dan dorongan yang positif kepada penderita dalam menjalani hidup agar penderita dapat lebih bersemangat dalam menjalani kehidupannya.

3. Bagi Peneliti Selanjutnya

Bagi peneliti selanjutnya yang ingin melakukan penelitian dengan bidang ini, diharapkan untuk menjadikan penelitian ini sebagai perbandingan untuk penelitian selanjutnya di lokasi yang berbeda dengan penambahan atau mengganti variabel-variabel yang akan diteliti serta mempersempit rentang usia pada subjek.

\section{Daftar Pustaka}

Azis, A., \& Fatma, A. (2013). Hubungan antara dukungan sosial dengan penyesuaian diri orangtua yang memiliki anak autis. Jurnal Talenta Psikologi, 11(2), 141-159. Diunduh dari http://download. portalgaruda.org/article.php?article $=140450 \&$ val $=5790$

Baron, R. A., \& Byrne, D. (2000). Social psychology. United Stated of America: Allyn and Bacon.

Cooper, T. D. (2003). Sin, pride \& self acceptance: the problem of identity in theology \& psychology. Downers Grove, IL: Inter Varsity Press.

Feist, J., \& Feist, G. J. (2006). Theories of personality (Ed. 5). Boston: McGraw-Hill.

Gea, A., Wulandari, A. P., \& Babari, Y. (2002). Relasi dengan diri sendiri. Jakarta: Gramedia.

Hurlock, E. B. (2006). Psikologi Perkembangan : Suatu Pendekatan Sepanjang Rentang Kehidupan (Edisi 6). Jakarta: Erlangga.

Kementerian Kesehatan, R. I. (2015). Situasi penyakit kanker. Pusat Data Dan Informasi, 1-6. Diunduh dari http://www.depkes.go.id/resources/download/pusdatin/infodatin/infodatin-kanker.pdf.

Mahleda, M., \& Hartini, N. (2012). Post traumatic growth pada pasien kanker payudara pasca mastektomi usia dewasa madya. Jurnal Psikologi Klinis Dan Kesehatan Mental, 1(2), 67-71. Diunduh dari http://journal.unair.ac.id/filerPDF/110810226_3v.pdf

Novianti, F. A. \& Purnami, S. wulan. (2012). Analisis diagnosis pasien kanker payudara menggunakan regresi logistik dan support vector machine (SVM) berdasarkan hasil mamografi. Jurnal Sains Dan Seni, 1(1), 148-152. Diunduh dari http://ejurnal2.its.ac.id/index.php/sains_seni/article/viewFile/1937/317.

Rasjidi. (2010). Epidemiologi kanker pada wanita. Jakarta: Sagung Seto.

Rizkiana,U., \& Retnaningsih. (2009). Penerimaan diri pada remaja penderita leukemia. Jurnal ilmiah $\begin{array}{lccl}\text { psikologi, } & 2(2), & 2-18 . & \text { Diunduh } \\ \text { http://id.portalgaruda.org/?ref=browse \&mod=viewarticle\&article=23949 }\end{array}$ 
Saputri, M. A. W. \& Indrawati, E. S. (2011). Hubungan antara dukungan sosial dengan depresi pada lanjut usia yang tinggal di panti wreda wening wardoyo Jawa Tengah. Jurnal Psikologi Undip, 9(1), 65-72. Diunduh dari http://ejournal.undip.ac.id/index.php/psikologi/article/view/2910

Sarafino, E. (2011). Social support : Health Psychology. New York: John wiley\&Sons, Inc.

Sari, E. P. \& Nuryoto, S. (2002). Penerimaan diri pada lanjut usia ditinjau dari kematangan emosi. Jurnal Psikologi, 2, 73-88. Diunduh dari https://jurnal.ugm.ac.id/jpsi/article/view/7017

Sumiatin, T. (2013). Hubungan pengetahuan dengan upaya pencegahan kanker payudara pada wanita usia subur di kecamatan Semanding kabupaten Tuban. Jurnal Keperawatan, 4 (2), 152-159. Diunduh dari http://ejournal.umm.ac.id/index.php/keperawatan/article/download/2366/323

Ulina, M. O., Kurniasih, O. I., \& Putri, D. E. (2013). Hubungan religiusitas dengan penerimaan diri pada masyarakat miskin. Jurnal Psikologi, Vol.5, 17-21. Diunduh dari http://ejournal.gunadarma.ac.id/index.php/pesat/article/download/903/793.

Waqiati, H. A., Hardjajani, T., \& Nugroho, A. A. (2013). Hubungan antara dukungan sosial dan efikasi diri dengan kecemasan menghadapi dunia kerja penyandang tuna daksa. Jurnal Psikologi, 2(1), $1-12$.

Diunduh

dari

http://id.portalgaruda.org/index.php?ref=browse\&mod=viewarticle\&article=260684 